\title{
Arsenic trioxide ameliorates experimental autoimmune encephalomyelitis in C57BL/6 mice through inducing apoptosis of CD4+ T cells
}

Ke An

Xiamen University

Mengjiao Xue

Xiamen University

Jiaying Zhong

Xiamen University

Shengnan Yu

Xiamen University

Zhongquan Qi

Guangxi University

JunjieXia ( $\nabla$ xia@xmu.edu.cn )

Xiamen University

\section{Research}

Keywords: Experimental autoimmune encephalomyelitis, arsenic trioxide, CD4 + T cells, apoptosis

Posted Date: January 17th, 2020

DOI: https://doi.org/10.21203/rs.2.21122/v1

License: (c) (i) This work is licensed under a Creative Commons Attribution 4.0 International License.

Read Full License

Version of Record: A version of this preprint was published at Journal of Neuroinflammation on May 6th, 2020. See the published version at https://doi.org/10.1186/s12974-020-01829-x. 


\section{Abstract}

Background: Multiple sclerosis (MS) is an autoimmune disease of central nervous system characterized by severe demyelination of white matter. There is still no definite cure for MS because of its complex pathogenesis. Experimental autoimmune encephalomyelitis (EAE) is an ideal animal model for the study of MS. Arsenic trioxide (ATO) is an ancient Chinese medicine that is used as a therapeutic application for many autoimmune diseases. It is also used to inhibit acute immune rejection because of its antiinflammatory and immunosuppressive properties. However, it is unclear if ATO has a curative effect on $\mathrm{EAE}$, and the underlying mechanisms have not been clearly elucidated. In this study, we attempted to explore the possibility of using ATO to ameliorate EAE in mice.

Methods: ATO $(0.5 \mathrm{mg} / \mathrm{kg} /$ day $)$ was administered intraperitoneally to EAE mice 10 days postimmunization for 8 days. On day 22 post-immunization, the spinal cord, spleen, and blood were collected to analyze demyelination, inflammation, microglia activation, and proportion of CD $4+T$ cells. In vitro, to further investigate the mechanism that underly the ameliorating effects of ATO in EAE mice, CD $4+T$ cells were traeted with ATO and then used for apoptosis assay, JC-1 staining, transmission electron microscope, and western bloting.

Results: We found that ATO alleviated the severity of EAE in mice. Treatment with ATO also attenuated demyelination, alleviated inflammation, reduced microglia activation and decreased the expression of IL2, IFN- $y$, IL-1 $\beta$, IL-6, and TNF- $\alpha$ in EAE mice. Moreover, the number and proportion of CD4 + T cells in the spinal cord, spleen, and peripheral blood were reduced in ATO-treated EAE mice. Finally, ATO induced CD4 $+T$ cells apoptosis through the mitochondrial pathway both in vitro and in vivo. Additionally, the administration of ATO had no adverse effect on liver and kidney function and did not induce apoptosis in the spinal cord.

Conclusions: Overall, our findings indicated that ATO plays a protective role in the initiation and progression of EAE and has the potential to be a novel drug in the treatment of MS.

\section{Background}

Multiple sclerosis (MS) is an autoimmune disorder of central nervous system (CNS) that is typically characterized by autoreactive $\mathrm{CD} 4^{+} \mathrm{T}$ cells-mediated neuroinflammation, demyelinated white matter, gliosis, and blood-brain barrier damage [1]. MS mainly occurs between 20 and 40 years of age, and it is the second largest neurological disease that causes disability in the young people [2, 3]. Currently, glucocorticoids, interferon beta (IFN- $\beta$ ), natalizumab, and fingolimod are commonly used treatments for MS [4]. However, these drugs are only effective for some MS patients. Additionally, the long-term effects of these treatments are associated with complications [5]. Consequently, there is an urgent need to develop a novel, safe, and effective therapeutic drug.

Experimental autoimmune encephalomyelitis (EAE) is an ideal animal model for the study of MS that is induced by immunization with myelin oligodendrocyte glycoprotein $\left(\mathrm{MOG}_{35}-55\right)$ in $\mathrm{C} 57 \mathrm{BL} / 6$ mice $[6,7]$. 
Although the pathogenesis of MS remains unclear, autoreactive $\mathrm{CD} 4^{+} \mathrm{T}$ cells-mediated neuroinflammatory responses are considered to result in the damage of spinal cord and brain [8]. Studies have noted that Th1 cells are involved in the initiation of EAE pathogenesis [9]. When the local cytokine environment contains IL-12 and IFN- $\gamma$, naïve CD $4^{+} T$ cells can be selectively induced to express T-bet and further differentiate into Th1 cells to activate macrophages and contribute to cellular immunity by secreting IFN-y, IL-2, and TNF-a [10].

Arsenic trioxide (ATO) is an ancient Chinese medicine that has been reported to treat syphilis and trypanosomiasis, which both damage the CNS $[11,12]$. In the 19th century, ATO was successfully approved as the frontline agent for the treatment of acute promyelocytic leukemia $[13,14]$. Recently, numerous reports has indicated that ATO is a novel and efficacious therapeutic drug in the treatment of autoimmune diseases, such as asthma [15], and human lupus-like syndrome [16]. Our previous work demonstrated that ATO attenuated acute rejection and prolonged graft survival in mice after heart transplantation [17] and in islet transplantation models [18]. These findings indicate that ATO elicits antiinflammatory and immunosuppressive effects. However, it is not clear whether ATO shows a therapeutic effects in EAE.

In this study, we assessed the therapeutic effects of ATO in EAE mice by evaluating differences in the clinical symptoms, histology and microglial activation in the spinal cord, inflammatory factor expression, and proportion of $\mathrm{CD} 4^{+} \mathrm{T}$ cells between ATO-treated and non-treated mice. Additionally, we also investigated the mechanism that underly the ameliorating effects of ATO in EAE mice.

\section{Materials And Methods}

\section{Mice}

Female C57BL/ 6 mice (6-8 weeks old, $20 \pm 2 \mathrm{~g}$ ) were purchased from Vitallihua Experimental Animal Co., Ltd. (Beijing, China). All the mice were housed in a specific pathogen-free facility. All animals and experiments used in this study were approved and performed in accordance with the guidelines of the Animal Ethics Committee of Xiamen University.

\section{EAE induction and ATO treatment}

To induce $E A E$, mice were immunized with $200 \mu \mathrm{g}$ of $\mathrm{MOG}_{35-55}$ peptide (BAM Biotech Co., Ltd., Xiamen, China) in complete freund's adjuvant (Sigma, MO, USA) supplemented with $2.5 \mathrm{mg} / \mathrm{mL}$ H37RA (Cohesion Biosciences, CA, England). 500 ng of pertussis toxin (List Biological Laboratories Inc., CA, USA) was administered intraperitoneally on the day of immunization and $48 \mathrm{~h}$ later. The clinical symptoms were scored as follows: 0 , normal; 1 , tail paralysis; 2 , partial hindlimbs paralysis; 3 , complete hindlimbs paralysis; and 4, complete hindlimbs paralysis and partial forelimbs weakness. Animals $(n=30)$ were randomly divided into three groups: control, no treatment; EAE, MOG treatment; and EAE + ATO (MOG combined ATO treatment). Ten days post-immunization, mice in the EAE + ATO group was 
intraperitoneally injected with ATO $(0.5 \mathrm{mg} / \mathrm{kg} /$ day $)$ for 8 days. On day 22 post-immunization, mice were sacrificed and peripheral blood, spinal cord, and spleen were collected and used for further experiments.

\section{Histopathology, Immunohistochemistry and Immunofluorescence}

The spinal cord was dissected and fixed with ice-cold $4 \%$ paraformaldehyde overnight at $4{ }^{\circ} \mathrm{C}$, embedded in paraffin, cut into $5 \mu \mathrm{m}$ slices, and stained with luxol fast blue (LFB) and hematoxylin and eosin (HE). LFB-stained sections were scored for demyelination as follows: 0 , none; 1 , rare foci; 2 , a few areas of demyelination; 3 , one to two large areas of demyelination; and 4, extensive demyelination. HE-stained sections were also scored for inflammation as follows: 0 , none; 1 , a few scattered inflammatory cells; 2 , perivascular infiltrates; 3 , extensive perivascular cuffing with extension into adjacent parenchyma; and 4, extensive cell infiltration in the white matter [19]. Additionally, the sections were subjected to indirect immunostaining. The primary antibodies were used as follows: anti-CD4 (1:70, Servicebio, Wuhan, China), anti-MBP (1:50, Boster, Wuhan, China), and anti-Iba-1 (1:200, Servicebio). Staining was quantified using the HALO ${ }^{\mathrm{TM}}$ image analysis software (Indica Labs, NM, USA).

\section{Proinflammatory cytokine detection}

Blood was obtained from the eyeball and kept at room temperature for $30 \mathrm{~min}$. After centrifugation at $4000 \mathrm{rpm}$ for $20 \mathrm{~min}$, the serum was transferred into a new tube and stored at $-80^{\circ} \mathrm{C}$. The concentration of IFN- $y$ in serum was measured using a commercial V-PLEX proinflammatory panel 1 kit (MSD, NJ, USA).

\section{Flow cytometry}

Red blood cells were removed to obtain peripheral and spleen lymphocytes. The cells were incubated in anti-CD4-FITC (Biolegend, CA, USA) at $4{ }^{\circ} \mathrm{C}$ for $30 \mathrm{~min}$. The stained CD4 ${ }^{+} \mathrm{T}$ cells were examined by flow cytometry with Beckman Cytoflex S (CA, USA). All data from flow cytometry were processed using FlowJo software V.10.

\section{Apoptosis}

Apoptosis of $\mathrm{CD}^{+}{ }^{+} \mathrm{T}$ cells was detected with the Annexin V-FITC/PI Detection Kit (Meilunbio, Dalian, China). Briefly, after washing with PBS, cells were stained with Annexin V-FITC and PI for 15 min at room temperature. Subsequently, cells were detected by flow cytometry with Beckman Cytoflex S. Apoptosis signals of spinal cords were examined with the Apoptosis Detection Kit (Servicebio).

\section{JC-1 staining}

$\mathrm{CD} 4^{+} \mathrm{T}$ cells were sorted from the spleen with the Mouse $\mathrm{CD} 4^{+} \mathrm{T}$ cell Isolation Kit (Miltenyi, Bergisch Gladbach, Germany), seeded in 12-well plates, and treated with $5 \mu \mathrm{g} / \mathrm{mL}$ ConA or ATO (1, and $2 \mu \mathrm{M})$ for $24 \mathrm{~h}$. JC-1 staining was performed to monitor the change of mitochondrial membrane potential. Briefly, the $\mathrm{CD}^{+} \mathrm{T}$ cells were incubated with $1640 \mathrm{RPMI}$ medium contained $10 \mathrm{mg} / \mathrm{mL}$ JC- 1 probe (Sigma) for 30 
min at $37^{\circ} \mathrm{C}$. After washing three times with PBS, the stained cells were examined by flow cytometry with Beckman Cytoflex S.

\section{Transmission electron microscope (TEM)}

$\mathrm{CD} 4^{+} \mathrm{T}$ cells were cultured and treated as described above. After washing with PBS, the cells were fixed with $2.5 \%$ glutaraldehyde overnight at $4{ }^{\circ} \mathrm{C}$. The following day they were fixed again with $1 \%$ osmiun tetroxide for $2.5 \mathrm{~h}$ at room temperature. Subsequently, the cells were embeded after dehydration. Ultrathin sections were counterstained with uranyl acetate for $30 \mathrm{~min}$ and lead citrate for $30 \mathrm{~s}$ and observed by a TEM (HT7800, Hitachi).

\section{Caspase 3 Activity Assays}

Total protein was extracted from $\mathrm{CD} 4^{+} \mathrm{T}$ cells to measure Caspase 3 activity with the Caspase 3 Activity Assay kit (Applygen, Beijing, China). Briefly, BCA assay was used to determine the protein concentrations; then, $10 \mu \mathrm{L}$ of Caspase 3 substrate was incubated with $10 \mu \mathrm{L}$ of the total protein $(30 \mu \mathrm{g})$ in a final volume of $100 \mu \mathrm{L}$ for $3 \mathrm{~h}$ at $37^{\circ} \mathrm{C}$. The absorbance of $p$-nitroanilide was measured using a microplate reader (Thermo Fisher Scientific, Waltham, MA, USA) at $405 \mathrm{~nm}$ in turn to calculate the Caspase 3 activity.

\section{Quantitative real-time PCR (qRT-PCR)}

Total RNA was extracted from spinal cords or spleen with Trizol (TansGen, Beijing, China). Reverse transcription was performed using the cDNA Synthesis SuperMix for qPCR kit (TansGen). The mRNA expression was quantified using qPCR SuperMix kit (TansGen) and normalized to $\beta$-actin. The sequences of primers are as follows: IL-1 $\beta$, forward 5'-TCGCAGCAGCACATCAACAAGAG-3', reverse 5'TGCTCATGTCCTCATCCTGGAAGG-3'; IL-2, forward 5'-GGAGCAGCTGTTGATGGACCTAC-3, reverse 5'AATCCAGAACATGCCGCAGAG-3'; IL-6, forward 5'-TGGGACTGATGCTGGTGACA-3', reverse 5'ACAGGTCTGTTGGGAGTGGT-3'; IFN- $\gamma$, forward 5'-CGGCACAGTCATTGAAAGCCTA-3', reverse 5'GTTGCTGATGGCCTGATTGTC-3'; TNF-a, forward 5'-GCCTCTTCTCATTCCTGCTTGTGG-3', reverse 5'GTGGTTTGTGAGTGTGAGGGTCTG-3'; MBP, forward 5'-GCTCTGGCAAGGACTCACACAC-3', reverse 5'TGGAGGTGGTGTTCGAGGTGTC-3'; $\beta$-actin, forward 5'-CATCCGTAAAGACCTCTATGCCAAC-3', reverse 5'ATGGAGCCACCGATCCACA-3'.

\section{Western blot}

Spinal cords were homogenized and $\mathrm{CD} 4^{+} \mathrm{T}$ cells were lysed with cold RIPA buffer (Proteintech, IL, USA) supplemented with a protease inhibitor cocktail (Sigma). After centrifugation at $4{ }^{\circ} \mathrm{C}$ for $15 \mathrm{~min}$, the supernatants were collected and used for western blot analysis. The following antibodies were used: antiBax (1:1000, Proteintech, IL, USA), anti-MBP (1:1000, Proteintech), anti-cleaved Caspase 3 (1:1000, Affinity, OH, USA), anti-cleaved Caspase 9 (1:1000, Affinity), anti-Bcl-2 (1:1000, Proteintech), anti-cleaved PARP (1:1000, Affinity), anti- $\beta$-actin (1:5000, Bioworld, MN, USA).

\section{Statistical analysis}


Data are analyzed with GraphPad Prism 6 software (La Jolla, CA, USA) and represented as means \pm SD of three separate experiments. All analysis of multiple comparisons were performed using a one-way ANOVA. A $p$ value $₫ 0.05$ was considered to be statistically significant.

\section{Results}

ATO ameliorated EAE progression in mice

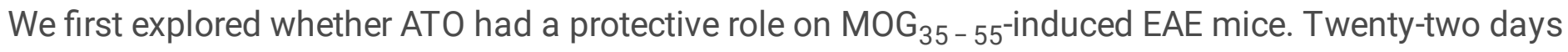
after immunization, EAE mice exhibited severe clinical signs with flaccid tail and complete paralysis of the hindlimbs; however, ATO-treated EAE mice only showed tail paralysis (Fig. 1a). EAE clinical score data showed that the onset of symptoms was lower in ATO-treated mice (day 22) as compared with that in EAE mice (day 18), and the maximal score (1.5) and mean score (1.02 \pm 0.04$)$ were lower in ATO-treated mice than the maximal (3.0) and mean score (1.86 \pm 0.39$)$ in EAE mice. (Fig. 1b). Additionally, weight loss was lower in ATO-treated mice than that in EAE mice (Fig. 1c). These suggest that ATO could effectively alleviate the severity of EAE in mice.

ATO alleviated demyelination in the spinal cord of EAE mice

To further confirm the therapeutic effects of ATO on EAE mice, we measured demyelination in spinal cord using LFB staining. The results showed that the area of demyelination in the spinal cord of EAE mice was large than that in ATO-treated EAE mice (Fig. 2a, c). Similarly, treatment with ATO significantly increased the expression of MBP, a structural protein of myelin, compared to that in the EAE group. (Fig. 2b, d-f). Overall, these findings suggest that ATO alleviated myelin damage associated with the progression of EAE.

ATO reduced inflammation in the spinal cord of EAE mice

Since $E A E$ is an autoimmune disease that is associated with severe neuroinflammation, we investigated whether ATO could decrease inflammatory cell infiltration, microglia activation, and inflammatory cytokine levels. Our results showed that EAE mice exhibited the extent of inflammatory cell infiltration in the spinal cord, wherease ATO-treated EAE mice showed only mild infiltration (Fig. 3a, c). Additionally, microglia activation (as evidenced by Iba-1 expression) in the spinal cord was dramatically reduced in ATO-treated EAE mice as compared with that in EAE mice (Fig. 3b, d). Moreover, treatment with ATO decreased the concentration of IFN- $y$ in serum of EAE mice (Fig. 3e). The expression of inflammatory cytokines, such as IL-2, IFN- $\gamma$, IL-1 $\beta$, IL-6, and TNF-a, were decreased in spinal cord of ATO-treated EAE mice as compared with that in EAE mice (Fig. 3f). Therefore, ATO appeared to reduce inflammatory cell infiltration and microglia activation during EAE progression.

ATO reduced the number and proportion of $\mathrm{CD} 4{ }^{+} \mathrm{T}$ cells in EAE mice by inducing apoptosis 
Since $\mathrm{CD} 4^{+} \mathrm{T}$ cells-mediated neuroinflammation are considered to result in the initiation of $\mathrm{EAE}$, we evaluated changes of $\mathrm{CD} 4^{+} \mathrm{T}$ cells in spinal cord, spleen, and blood. EAE induction led to the prominent infiltration of $\mathrm{CD}^{+} \mathrm{T}$ cells in the spinal cord; however, this effect was counteracted following treatment with ATO (Fig. 4a, b). Similarly, treatment with ATO significantly reduced the proportion of $\mathrm{CD} 4^{+} \mathrm{T}$ cells in the spleen (Fig. 4c, d) and peripheral blood (Fig. 4e, f) as compared with that in EAE mice.

Studies have reported that ATO induced apoptosis in a variety of cells, including T cells. Therefore, we investigated if the ATO-reduced proportion and population of $\mathrm{CD} 4^{+} \mathrm{T}$ cells in EAE mice was related to apoptosis induction. The ratio of apoptotic $\mathrm{CD} 4^{+} \mathrm{T}$ cells in spleen was significantly increased in ATOtreated EAE mcie as compared with that in EAE mice (Fig. 5a, b). Additionally, the amount of TUNEL positive signals was higher in EAE mice than that in ATO-treated EAE mice (Fig. 5c, d), showing that ATO decreased apoptosis in the spinal cord of EAE mice. Collectively, these results indicate that the decreased of $\mathrm{CD} 4^{+} \mathrm{T}$ cells in ATO-treated EAE mice may be attributed to apoptosis induction.

ATO induced $\mathrm{CD} 4{ }^{+}$apoptosis $\mathrm{T}$ cells through mitochondrial pathway

To investigate the underlying mechanism of ATO-induced apoptosis of in vitro, $\mathrm{CD} 4^{+} \mathrm{T}$ cells were isolated from naïve mice and cultured for 24 h. As shown in Fig. 6a, c, ATO significantly increased the ratio of apoptotic cells in a dose-dependent manner. The mitochondrial membrane potential was high in activated $\mathrm{CD} 4^{+} \mathrm{T}$ cells, whereas ATO treatment diminished the $\mathrm{J}$-aggregates and increased the $\mathrm{J}$ monomers (Fig. 6b, d). Moreover, transmission electron microscopic examination showed that mitochondria swelling, decrease or disappearance of mitochondria crista, and vacuolization were observed in ATO-treated groups (Fig. 6e). Meanwhile, the level of pro-apoptotic proteins, such as cleavedCaspase 3, Bax, cleaved-Caspase 9, and cleaved-PARP was significantly increased in ATO-treated EAE mcie; however ATO decreased Bcl-2 expression (Fig. 6f, g). Moreover, consistent to the results observed in vitro, ATO treatment significantly increased the level of pro-apoptotic proteins in the spleen of EAE mice, while decreased Bcl-2 expression (Fig. 6h, i). These data indicated that ATO induced CD $4^{+} \mathrm{T}$ cells apoptosis through the mitochondrial pathway both in vitro and in vivo.

No toxicity signs were evident in ATO-treated mice

To determine whether the administration of ATO had toxic effects on mice, we analyzed the functions of liver and kidney after consecutive intraperitoneal injections of ATO for 20 days. The results of HE staining showed that there were no obvious abnormalities the in liver or kidney in mice after ATO treatment as compared with control mice (Fig. 7a). Consistently, no significant differences in the levels of ALT, AST, creatinine, and urea were observed between ATO-treated mice and control mice, even at a dose of $1 \mathrm{mg} / \mathrm{kg} /$ day (Fig. 7b). Moreover, treatmen with ATO did not result in evident TUNEL positive signals in the spinal cord (Fig. 7c). These results suggested that ATO had no adverse effect on liver and kidney function at a dose of 0.5 or $1 \mathrm{mg} / \mathrm{kg} /$ day and did not induce apoptosis in the spinal cord.

\section{Discussion}


Our results indicated that ATO alleviated the clinical signs and severity of EAE in mice. Treatment with ATO attenuated demyelination and inflammatory infiltration and decreased microglia activation and TUNEL positive signals in spinal cord of EAE mice. Additional data showed that ATO reduced the number and proportion of $\mathrm{CD} 4^{+} \mathrm{T}$ cells in EAE mice. Most importantly, further investigation found that CD $4^{+} \mathrm{T}$ cells apoptosis contributed to the therapeutic effect of ATO in EAE mice. Overall, our results suggest that ATO has the potential to treat MS and other autoimmune diseases.

MS is an autoimmune disorder that is characterized by neuroinflammation and demyelination in the CNS [20]. In the present study, EAE was induced by immunization with $\mathrm{MOG}_{35-55}$ in female C57/BL6 mice for the study of MS. In EAE mice, microglia, which provoke axonal damage and support repair mechanisms, are crucial for the development of EAE [21]. The abnormal activation of microglia result in damge of myelin, axonal and neuron, which are mediated by expressing high levels of oxidative stress and iNOS as well as excessively releasing some cytotoxic mediators, including chemokines and proinflammatory cytokines IL-6, IL-1 $\beta$, and TNF-a $[22,23]$. In this study, the result showed that treatment with ATO reduced the expression of Iba-1 indicating that ATO decreased microglial activation in spinal cord of EAE mice. Consequently, part of the therapeutic effects of ATO in EAE mice may be due to its ability to inhibit microglia activation in spinal cord and ultimately impair informatory steps that lead to myelin damage.

Inhibition of the release of some proinflammatory cytokines is an effective strategy to attenuate EAE clinical symptoms. IFN-y and IL-6 can induce the expression of chemokines and adhesion molecules, which recruit the migration of leukocytes into the CNS $[24,25]$. In the CNS, IL-1 $\beta$ can recruit and activate lymphocytes through acting on astrocytes and CNS endothelial cells to stimulate the secretion of proinflammatory cytokines and chemokines [26]. TNF-a produced by infiltrated macrophagese can exacerbate the severity of EAE through promoting inflammatory infiltrates and disrupting the blood-brain barrier [27]. Our data demonstrated that treatment with ATO decreased the mRNA level of inflammatory cytokines in the spinal cord and reduced the concentration of IFN- $\gamma$ in the serum of EAE mice. Consistent with our findings, studies have reported that ATO reduced inflammation in splenocytes of MRL/Ipr mice and human lupus peripheral blood mononuclear cells by reducing the expression level of the INF- $\mathrm{Y}$ [28]. Collectively, the therapeutic effects of ATO in our study may be partially due to lower expression of proinflammatory cytokines, such as IL-2, IFN- $y, I L-1 \beta, I L-6$, and TNF-a.

Although the etiology of MS remains unclear, it is generally accepted that autoreactive CD4 ${ }^{+} \mathrm{T}$ cells are involved in the initiating and orchestrating of neuroinflammation [29]. In the $\mathrm{MOG}_{35}-55^{\text {-induced }} \mathrm{EAE}$ mice, autoreactive $\mathrm{CD} 4^{+} \mathrm{T}$ cells cross the blood-brain barrier and infiltrate the CNS where they interact with antigen presenting cells and are reactivated. Therefore, pro-inflammatory products secreted by activated $\mathrm{CD}^{+} \mathrm{T}$ cells, such as chemokines and cytokines, attract various immune cells into the CNS where they initiate an inflammatory cascade and secrete mediators that damage CNS tissue. This gradually aggravate CNS demyelination and ultimately lead to the occurrence of EAE [30]. In our study, ATO decreased the proportion of $\mathrm{CD} 4^{+} \mathrm{T}$ cells in the spleen and peripheral blood; thus, the population of $\mathrm{CD}^{+} \mathrm{T}$ cells that migrated to the CNS was also reduced. Indeed, treatment with ATO decreased the 
number of $\mathrm{CD} 4^{+} \mathrm{T}$ cells infiltrates in the white matter. Hence, our findings suggest the therapeutic effects of ATO was partially produced by decreasing the infiltration and proportion of $\mathrm{CD} 4^{+} \mathrm{T}$ cells in the spinal cord and periphery of EAE mice.

Once $\mathrm{CD} 4^{+} \mathrm{T}$ cells are excessively activated and subsequently migrated into CNS, the white matter of spinal cord will undergo severe demyelination [31]. Hence, apoptosis induction of $\mathrm{CD} 4^{+} \mathrm{T}$ cells may contribute to treat MS. It has been reported that some clinical drugs, such as glatiramer acetate [32] and IFN- $\beta$ [33], treat MS by inducing the peripheral T cells apoptosis. Similarly, results from our study demonstrated that ATO induced $\mathrm{CD} 4^{+} \mathrm{T}$ cells apoptosis in spleen through the mitochondrial pathway; thus, the population of $\mathrm{CD} 4^{+} \mathrm{T}$ cells that infiltrated to the spinal cord was decreased and EAE symptoms were ameliorated. However, studies have not yet identified how to protect CNS from apoptosis while inducing $\mathrm{CD} 4^{+} \mathrm{T}$ cell apoptosis, and the treatment of MS needs to address this issue. Studies have been reported that ATO mediates microglia inflammatory responses and subsequent neuronal apoptosis [34]. Moreover, other studies found that apoptosis in spinal cord occurs during EAE progression [35, 36]. However, in this study, we found that treatment with $0.5 \mathrm{mg} / \mathrm{kg} /$ day ATO in EAE mice actually reduced TUNEL ${ }^{+}$cells in spinal cord. This finding suggests that if the dose of ATO is controlled within a certain range, spinal cord will be protected from apoptosis. Indeed, we did not observe any adverse effects on the organs in mice, and TUNEL positive signaling in the spinal cord was not observed after the administration of 0.5 or $1 \mathrm{mg} / \mathrm{kg} /$ day ATO for 20 days. Thus, we can conclude that ATO specifically induced apoptosis of $\mathrm{CD}^{+} \mathrm{T}$ cells in the periphery but not in the spinal cord of EAE mice, and this inhibited the infiltration of inflammatory cells into the CNS.

Cell apoptosis can be triggered by the mitochondria pathway, the endoplasmic reticulum stress pathway, and the death receptor-mediated extrinsic pathway. Among these pathways, the mitochondria pathway can be activated by caspase cascades and Bcl-2 family members in the mitochondria [37]. Other studies have reported that ATO-induced apoptosis is attributed to the downregulation of $\mathrm{Bcl}-2$, the upregulation of Bax, and reduction of the mitochondrial membrane potential [38]. Results from our study support these findings and demonstrate that ATO induced alterations in the protein level of Bcl-2 and Bax and decreased the mitochondrial membrane potential in $\mathrm{CD} 4^{+} \mathrm{T}$ cells. Therefore, the data indicate that ATO treatment can induce $\mathrm{CD} 4^{+} \mathrm{T}$ cells apoptosis through the intrinsic pathway both in vivo and in vitro.

\section{Conclusion}

In summary, our study suggested that ATO ameliorated EAE in C57BL/ 6 mice by inducing $\mathrm{CD} 4{ }^{+} \mathrm{T}$ cells apoptosis via the mitochondrial pathway. Additionally, the administration of ATO had no adverse effect on liver and kidney function and did not induce apoptosis in the spinal cord. These findings may facilitate the clinical application of ATO for the treatment of MS or other autoimmune diseases.

\section{List Of Abbreviations}


MS, multiple sclerosis; ATO, arsenic trioxide; EAE, experimental autoimmune encephalomyelitis; LFB, luxol fast blue; TEM, transmission electron microscope; qRT-PCR, quantitative real-time PCR; CNS, central nervous system; Th, T helper; FITC, fluorescein isothiocyanate; PBS, phosphate buffered saline; MBP, myelin basic protein; TUNEL, TdT-mediated dUTP nick end labeling; IFN- $\beta$, interferon beta; IL-1 $\beta$, interleukin-1 $\beta$; MOG, myelin oligodendrocyte glycoprotein; IL-2, interleukin-2; CFA, Complete Freund's Adjuvant; IL-6, interleukin-6; HE, hematoxylin and eosin; IFN-y, interferon gama; TNF-a, tumor necrosis factor-a; PTX, pertussis toxin; PI, Propidium lodide; ANOVA, analysis of variance. SD, standard deviation; ALT, alanine aminotransferase; AST, aspartic aminotransferase.

\section{Declarations}

Acknowledgments The authors thank Jian-Qi Zeng, Zhongshan Hospital, Xiamen University, for her help in establishment of EAE model. We also thank Xiang You and Hai-Ping Zheng, School of Medicine, Xiamen University, for their excellent technical assistance.

Authors' Contributions Z.Q. and J.X. made contributions to experimental design, data analysis, manuscript revision, and funding. K.A. performed the experiments, analyzed the data, and drafted the article. M.X., J.Z. and S.Y. performed the experiments.

Funding This study was supported by grants from the National Natural Science Foundation of China (81671583), the National Key R\&D Program of China (2018YFA0108304), the National Natural Science Foundation of China $(81971505,81771271,81971506)$, and the Fujian Provincial Health Education Joint Research Project (WKJ2016-2-20).

Availability of data and materials All data used in this study are available from the corresponding author on reasonable request.

Ethics approval and consent to participate All animals and experiments in this study were approved by the Animal Ethics Committee of Xiamen University.

Consent for publication Not applicable

Competing interests The authors declare that they have no competing interests.

\section{References}

1. Frohman EM, Racke MK, Raine CS. Multiple sclerosis--the plaque and its pathogenesis. N Engl J Med. 2006;354:942-55.

2. Sperandeo K, Nogrady L, Moreo K, Prostko CR. Managed approaches to multiple sclerosis in special populations. J Manag Care Pharm. 2011;17:S1-19; quiz S20-1.

3. Hassan-Smith G, Douglas MR. Management and prognosis of multiple sclerosis. Br J Hosp Med (Lond). 2011;72:M174-6. 
4. Hamana A, Takahashi Y, Tanioka A, Nishikawa M, Takakura Y. Amelioration of Experimental Autoimmune Encephalomyelitis in Mice by Interferon-Beta Gene Therapy, Using a Long-Term Expression Plasmid Vector. Mol Pharm. 2017;14:1212-7.

5. Weinstock-Guttman B. An update on new and emerging therapies for relapsing-remitting multiple sclerosis. Am J Manag Care. 2013;19:s343-54.

6. Baker D, Amor S. Experimental autoimmune encephalomyelitis is a good model of multiple sclerosis if used wisely. Mult Scler Relat Disord. 2014;3:555-64.

7. Linker RA, Lee DH. Models of autoimmune demyelination in the central nervous system: on the way to translational medicine. Exp Transl Stroke Med. 2009;1:5.

8. Pearce JM. Historical descriptions of multiple sclerosis. Eur Neurol. 2005;54:49-53.

9. Ando DG, Clayton J, Kono D, Urban JL, Sercarz EE. Encephalitogenic T cells in the B10.PL model of experimental allergic encephalomyelitis (EAE) are of the Th-1 lymphokine subtype. Cell Immunol. 1989;124:132-43.

10. Glimcher LH, Murphy KM. Lineage commitment in the immune system: the T helper lymphocyte grows up. Genes Dev. 2000;14:1693-711.

11. Dilda PJ, Hogg PJ. Arsenical-based cancer drugs. Cancer Treat Rev. 2007;33:542-64.

12. Perdrup A. Penicillin versus arsenical-bismuth treatment in early syphilis. Acta Derm Venereol Suppl (Stockh). 1950;31:44-8.

13. Au WY, Li CK, Lee V, Yuen HL, Yau J, Chan GC, Ha SY, Kwong YL. Oral arsenic trioxide for relapsed acute promyelocytic leukemia in pediatric patients. Pediatr Blood Cancer. 2012;58:630-2.

14. Iland HJ, Bradstock K, Supple SG, Catalano A, Collins M, Hertzberg M, Browett P, Grigg A, Firkin F, Hugman A, et al. All-trans-retinoic acid, idarubicin, and IV arsenic trioxide as initial therapy in acute promyelocytic leukemia (APML4). Blood. 2012;120:1570-80; quiz 752.

15. Chu KH, Lee CC, Hsin SC, Cai BC, Wang JH, Chiang BL. Arsenic trioxide alleviates airway hyperresponsiveness and eosinophilia in a murine model of asthma. Cell Mol Immunol. 2010;7:37580.

16. Bobe P, Bonardelle D, Benihoud K, Opolon P, Chelbi-Alix MK. Arsenic trioxide: A promising novel therapeutic agent for lymphoproliferative and autoimmune syndromes in MRL/Ipr mice. Blood. 2006;108:3967-75.

17. Li C, Guan T, Gao C, Lin Y, Yan G, Zhu M, Lv C, Xia J, Qi Z. Arsenic trioxide inhibits accelerated allograft rejection mediated by alloreactive $\mathrm{CD} 8(+)$ memory $T$ cells and prolongs allograft survival time. Transpl Immunol. 2015;33:30-6.

18. Gao C, Jiang J, Ma P, Cheng P, Lian Y, Zhao B, Li C, Peng Y, Wang F, Lin Y, et al. Arsenic Trioxide Induces T Cell Apoptosis and Prolongs Islet Allograft Survival in Mice. Transplantation. 2015;99:1796-806.

19. Rynda A, Maddaloni M, Ochoa-Reparaz J, Callis G, Pascual DW. IL-28 supplants requirement for $\mathrm{T}(\mathrm{reg})$ cells in protein sigma1-mediated protection against murine experimental autoimmune 
encephalomyelitis (EAE). PLoS One. 2010;5:e8720.

20. Hainz N, Wolf S, Tschernig T, Meier C. Probenecid Application Prevents Clinical Symptoms and Inflammation in Experimental Autoimmune Encephalomyelitis. Inflammation. 2016;39:123-8.

21. Heppner FL, Greter M, Marino D, Falsig J, Raivich G, Hovelmeyer N, Waisman A, Rulicke T, Prinz M, Priller $\mathrm{J}$, et al. Experimental autoimmune encephalomyelitis repressed by microglial paralysis. Nat Med. 2005;11:146-52.

22. di Penta A, Moreno B, Reix S, Fernandez-Diez B, Villanueva M, Errea O, Escala N, Vandenbroeck K, Comella JX, Villoslada P. Oxidative stress and proinflammatory cytokines contribute to demyelination and axonal damage in a cerebellar culture model of neuroinflammation. PLoS One. 2013;8:e54722.

23. Renno T, Krakowski M, Piccirillo C, Lin JY, Owens T. TNF-alpha expression by resident microglia and infiltrating leukocytes in the central nervous system of mice with experimental allergic encephalomyelitis. Regulation by Th1 cytokines. J Immunol. 1995;154:944-53.

24. Rothaug M, Becker-Pauly C, Rose-John S. The role of interleukin- 6 signaling in nervous tissue. Biochim Biophys Acta. 2016;1863:1218-27.

25. Raphael I, Nalawade S, Eagar TN, Forsthuber TG. T cell subsets and their signature cytokines in autoimmune and inflammatory diseases. Cytokine. 2015;74:5-17.

26. Lin CC, Edelson BT. New Insights into the Role of IL-1beta in Experimental Autoimmune Encephalomyelitis and Multiple Sclerosis. J Immunol. 2017;198:4553-60.

27. Valentin-Torres A, Savarin C, Hinton DR, Phares TW, Bergmann CC, Stohlman SA. Sustained TNF production by central nervous system infiltrating macrophages promotes progressive autoimmune encephalomyelitis. J Neuroinflammation. 2016;13:46.

28. Hu H, Chen E, Li Y, Zhu X, Zhang T, Zhu X. Effects of Arsenic Trioxide on INF-gamma Gene Expression in MRL/Ipr Mice and Human Lupus. Biol Trace Elem Res. 2018;184:391-7.

29. Yang L, Xing F, Han X, Li Q, Wu H, Shi H, Wang Z, Huang F, Wu X. Astragaloside IV regulates differentiation and induces apoptosis of activated CD4(+) T cells in the pathogenesis of experimental autoimmune encephalomyelitis. Toxicol Appl Pharmacol. 2019;362:105-15.

30. Rostami A, Ciric B. Role of Th17 cells in the pathogenesis of CNS inflammatory demyelination. J Neurol Sci. 2013;333:76-87.

31. Jadidi-Niaragh F, Mirshafiey A. Th17 cell, the new player of neuroinflammatory process in multiple sclerosis. Scand J Immunol. 2011;74:1-13.

32. Ruggieri M, Avolio C, Scacco S, Pica C, Lia A, Zimatore GB, Papa S, Livrea P, Trojano M. Glatiramer acetate induces pro-apoptotic mechanisms involving Bcl-2, Bax and Cyt-c in peripheral lymphocytes from multiple sclerosis patients. J Neurol. 2006;253:231-6.

33. Sharief MK, Semra YK, Seidi OA, Zoukos Y. Interferon-beta therapy downregulates the anti-apoptosis protein FLIP in T cells from patients with multiple sclerosis. J Neuroimmunol. 2001;120:199-207.

34. Mao J, Yang J, Zhang Y, Li T, Wang C, Xu L, Hu Q, Wang X, Jiang S, Nie X, et al. Arsenic trioxide mediates HAPI microglia inflammatory response and subsequent neuron apoptosis through 
p38/JNK MAPK/STAT3 pathway. Toxicol Appl Pharmacol. 2016;303:79-89.

35. Dasgupta A, Zheng J, Perrone-Bizzozero NI, Bizzozero OA. Increased carbonylation, protein aggregation and apoptosis in the spinal cord of mice with experimental autoimmune encephalomyelitis. ASN Neuro. 2013;5:e00111.

36. Duarte-Silva E, Araujo S, Oliveira WH, Los DB, Franca MER, Bonfanti AP, Peron G, Thomaz LL, Verinaud L, Nunes AKS, et al. Sildenafil ameliorates EAE by decreasing apoptosis in the spinal cord of C57BL/6 mice. J Neuroimmunol. 2018;321:125-37.

37. Chhabra A. Mitochondria-centric activation induced cell death of cytolytic T lymphocytes and its implications for cancer immunotherapy. Vaccine. 2010;28:4566-72.

38. Kumar S, Yedjou CG, Tchounwou PB. Arsenic trioxide induces oxidative stress, DNA damage, and mitochondrial pathway of apoptosis in human leukemia (HL-60) cells. J Exp Clin Cancer Res. 2014;33:42.

\section{Figures}
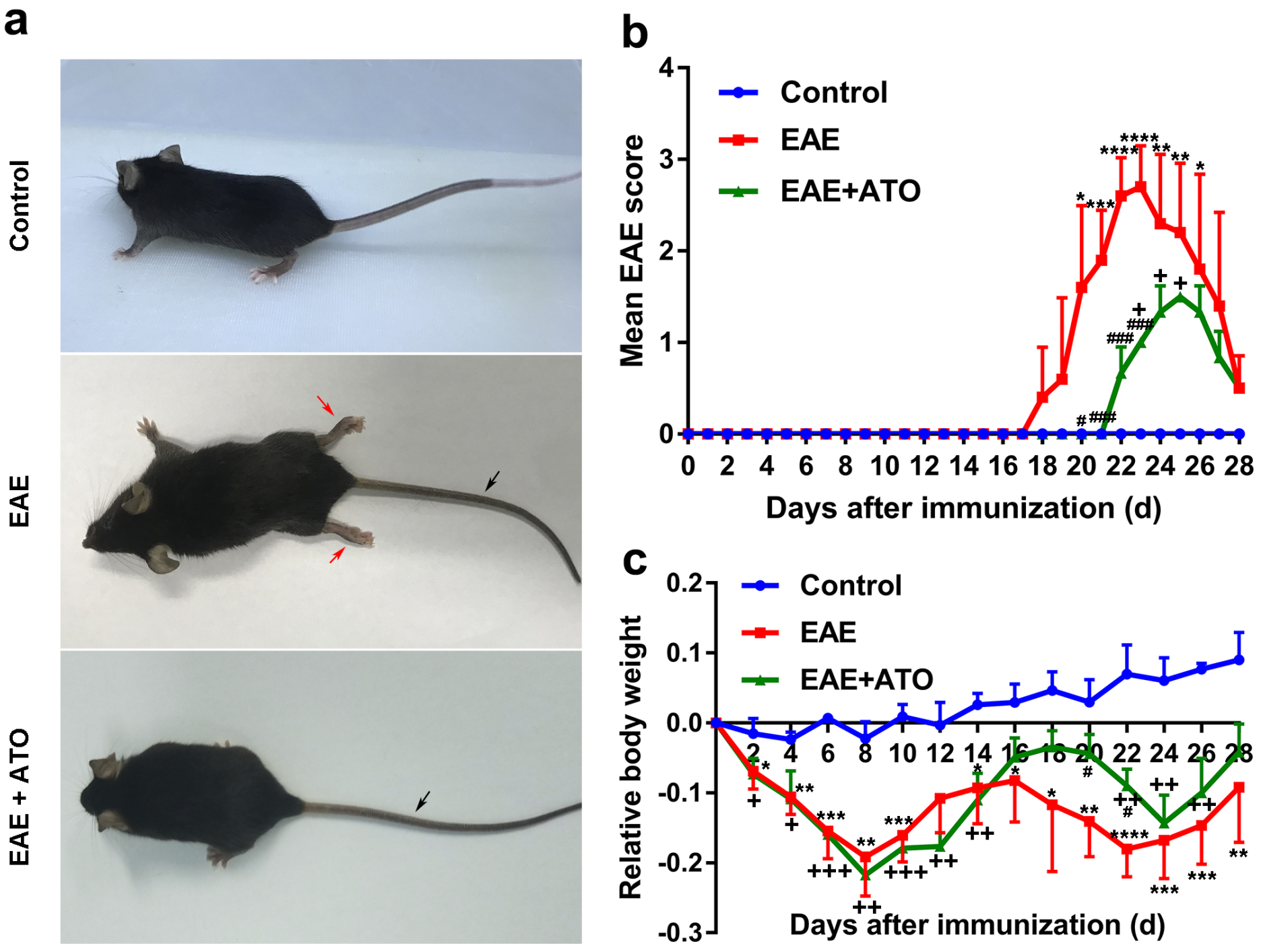
Figure 1

ATO ameliorates EAE progression in mice. a Representative images show behavioral symptoms of EAE mice in individual groups. Black arrow presents limp tail, and red arrow presents hind limb paralysis. The clinical scores (b) and changes in body weight (c) were recorded. $n=10$ /group. ${ }^{*} P<0.05, * \star P<0.01$, ${ }^{\star \star *} P$

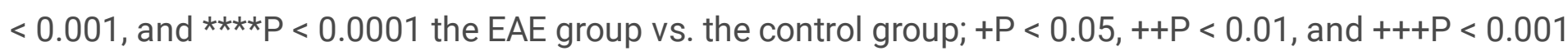
the EAE+ATO group vs. the control group; \#P $<0.05$ and \#\#\#P $<0.001$ the EAE+ATO group vs. the EAE group.
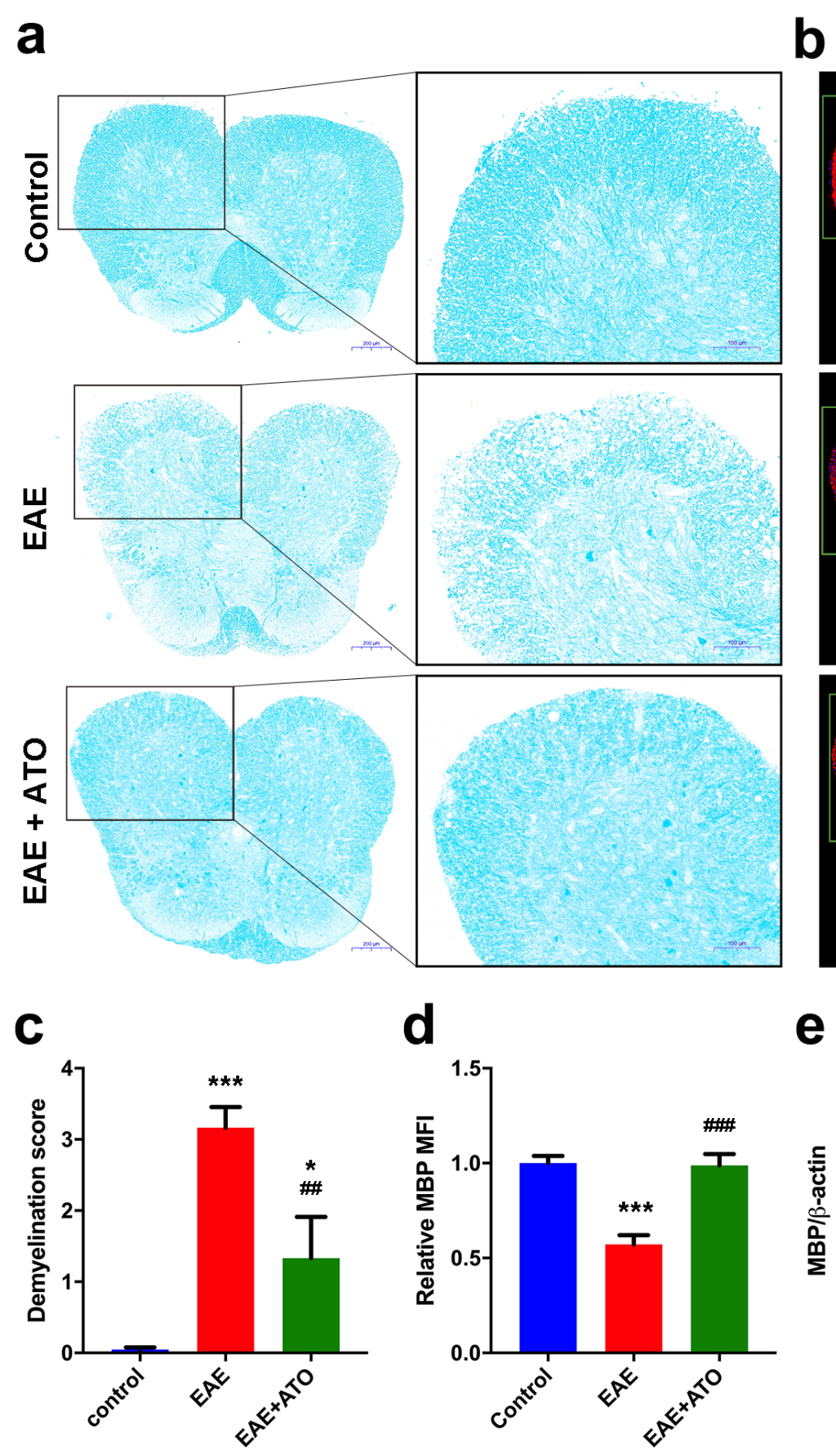

d

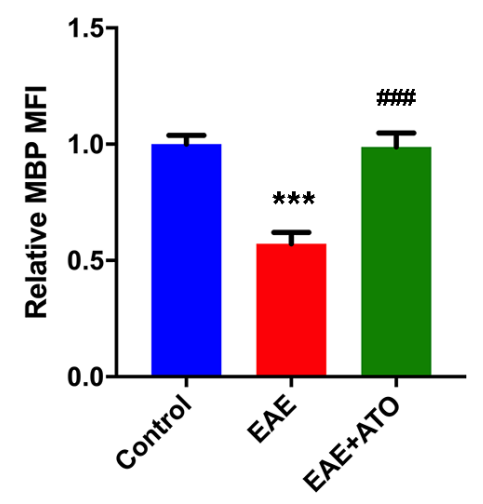

b
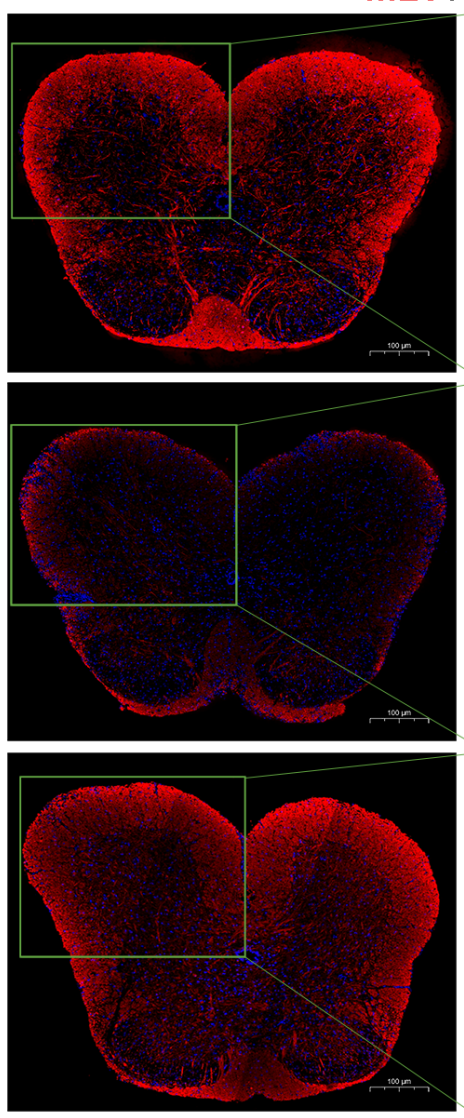

e

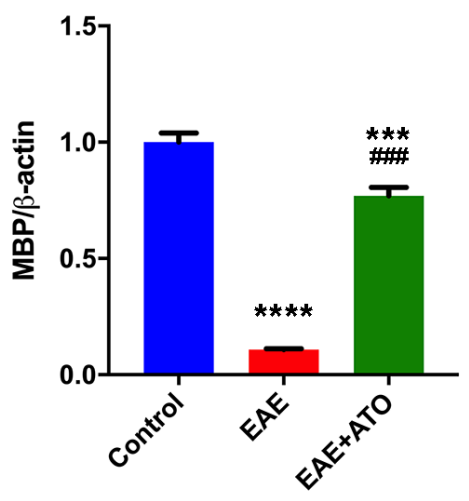

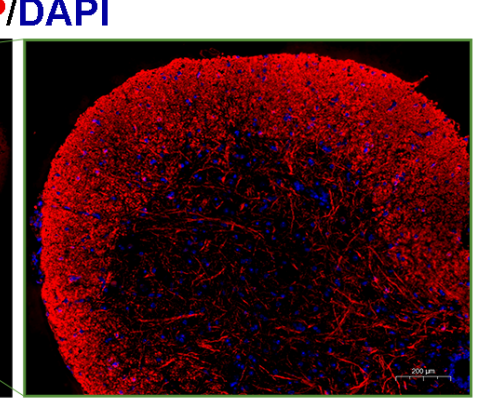
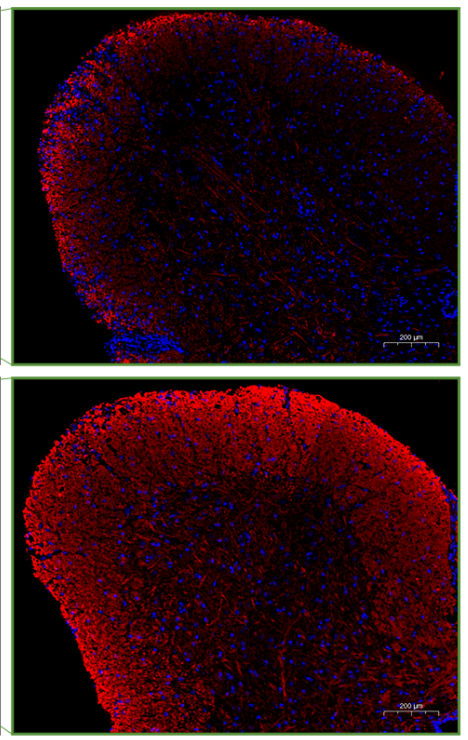

f

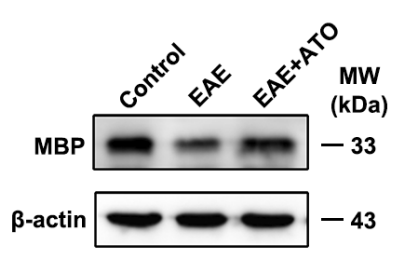

Figure 2 
ATO alleviates demyelination in the spinal cord of EAE mice. Representative LFB staining sections (a) and demyelination score (c) of spinal cord. Areas enclosed within black squares are magnified on the right. b Representative immunofluorescent staining sections of MBP in spinal cord. Areas enclosed within green squares are magnified on the right. $d$ Mean fluorescence intensity analysis of MBP in b. e The mRNA level of MBP in spinal cord was quantified by qRT-PCR. $f$ The protein level of MBP in spinal cord was analyzed by western blot. $n=3$ /group. ${ }^{*} P<0.05$, ${ }^{\star \star \star} P<0.001$, and ${ }^{\star \star \star \star} P<0.0001$ vs. the control group; $\# \# P<0.01$, $\# \# \# P<0.001$, and \#\#\#\#P $<0.0001$ vs. the EAE group.

a
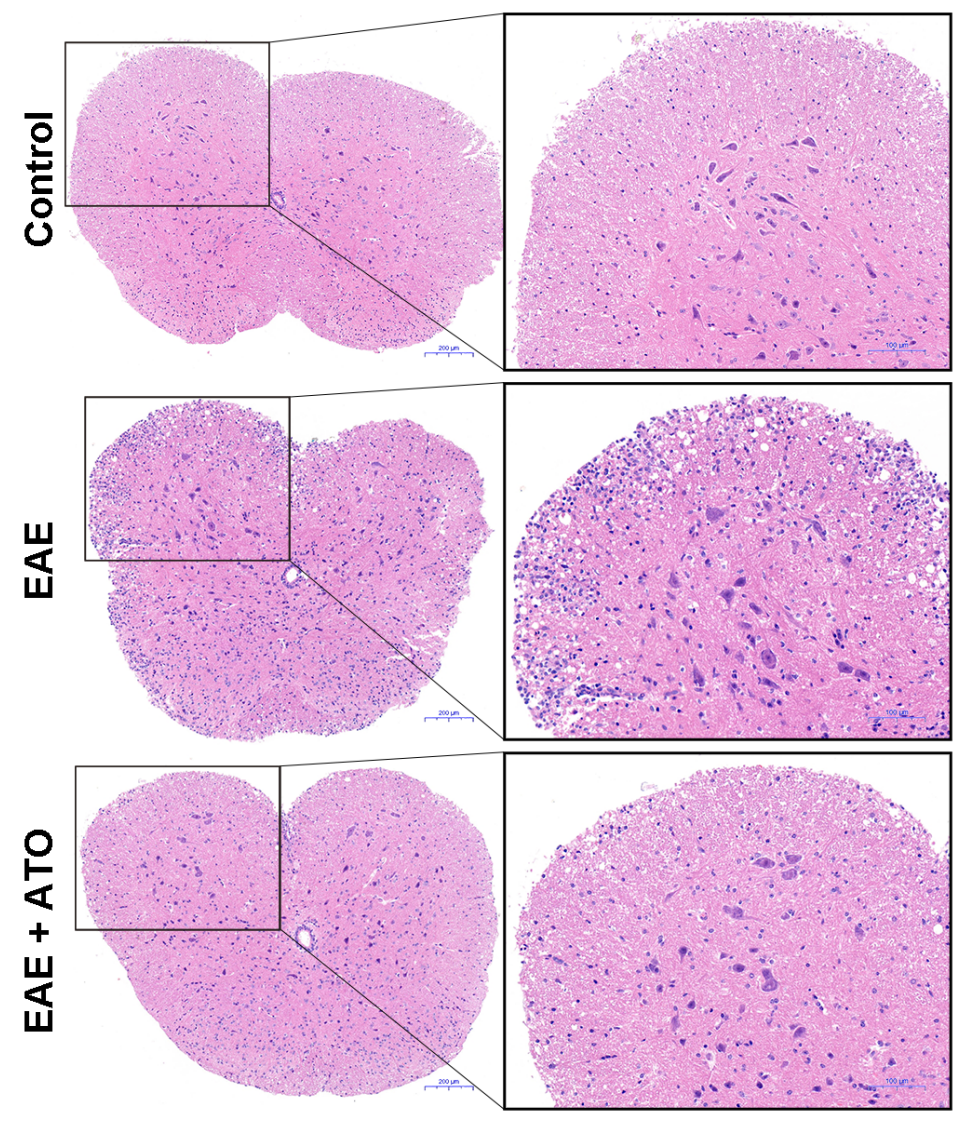

C
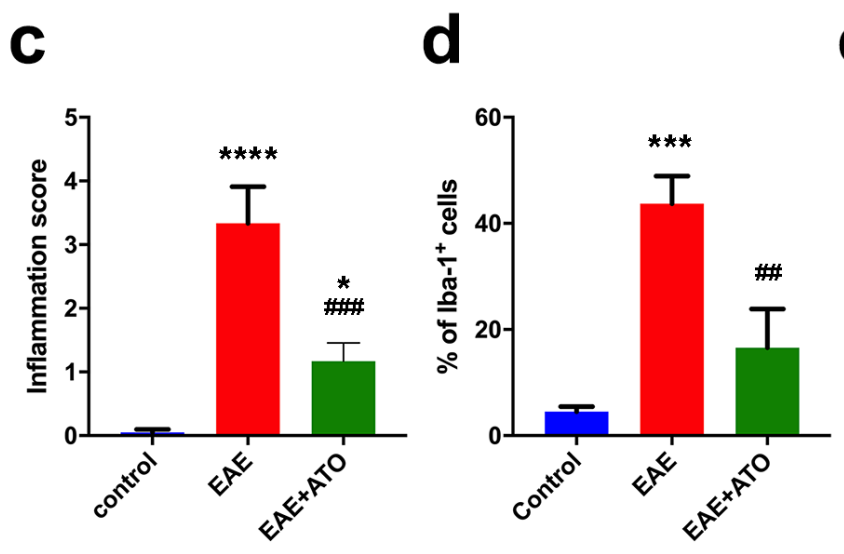

b
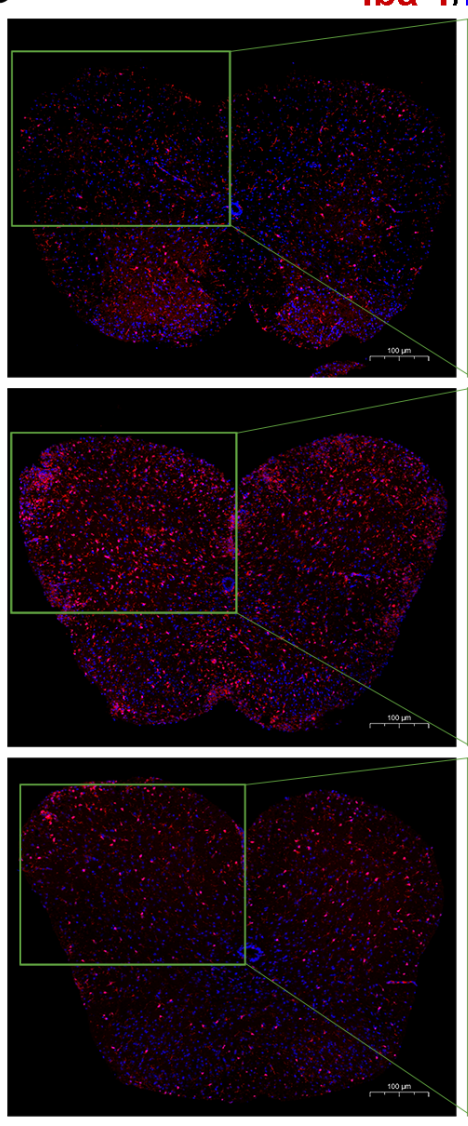

e

f
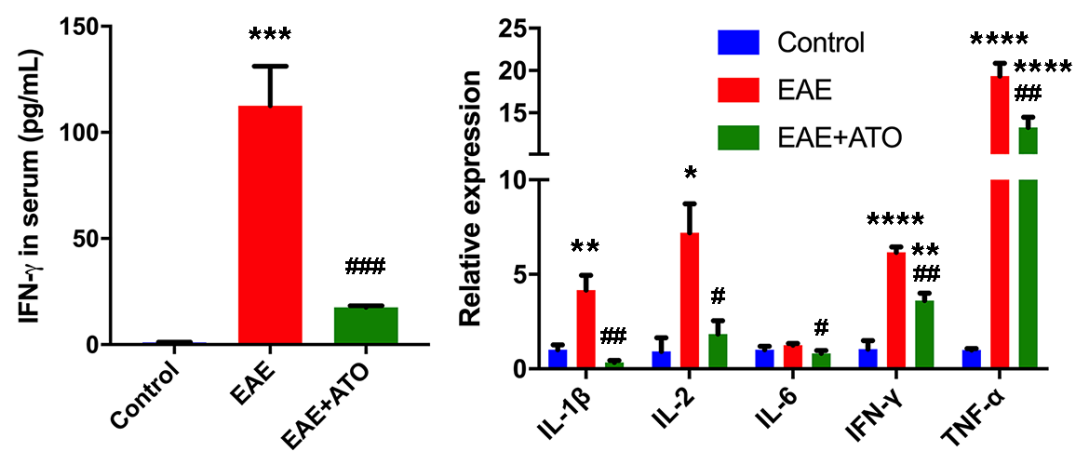

Figure 3

ATO reduces inflammation in the spinal cord of EAE mice. a Representative HE staining sections of spinal cord. Areas enclosed within black squares are magnified on the right. c Analysis of spinal cord infiltrates 
in a. b Iba-1 immunofluorescent staining in spinal cord. Areas enclosed within green squares are magnified on the right. $d$ Analysis of Iba-1+ cells in b. e Concentration of IFN- $y$ in the serum was measured with the V-PLEX proinflammatory panel 1 kit. $f$ The mRNA levels of inflammatory cytokines in the spinal cord were determined through qRT-PCR. $n=3$ /group. ${ }^{*} P<0.05, * * P<0.01,{ }^{* \star *} P<0.001$, and $\star \star \star * P<0.0001$ vs. the control group; $\# \mathrm{P}<0.05$, \#\#P $<0.01$, and \#\#\#P $<0.001$ vs. the EAE group.

a
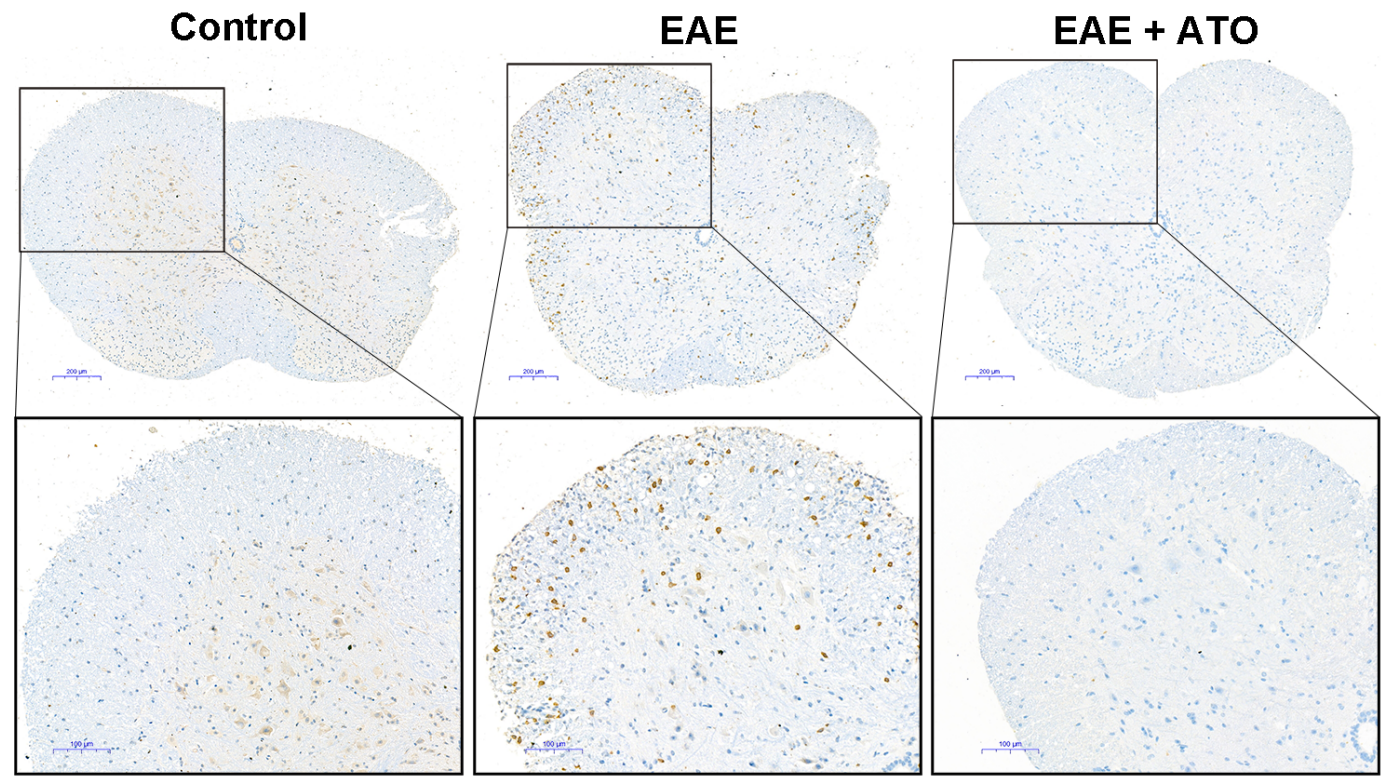

b
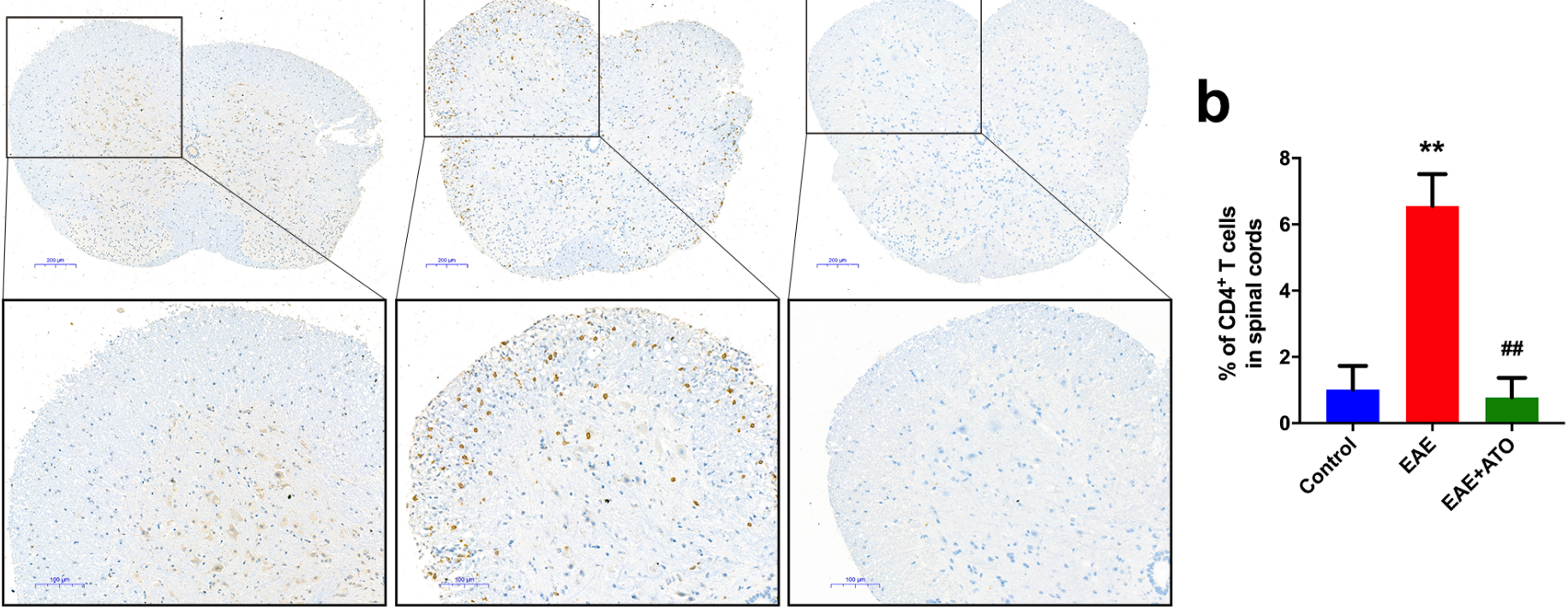

C
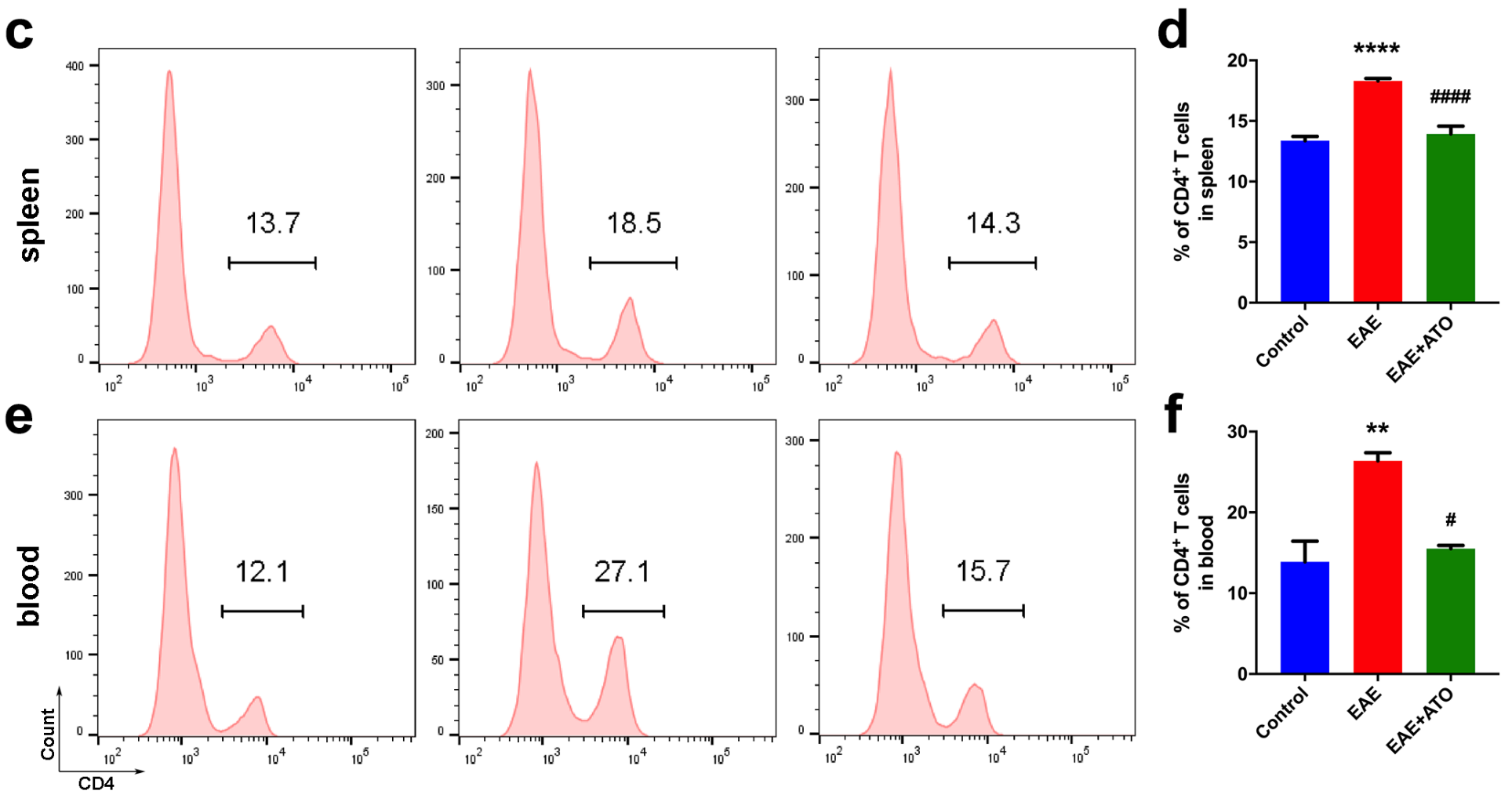

Figure 4

ATO reduces the number and proportion of CD4+ T cells in EAE mice. a Immunohistochemical staining of CD4 was performed in spinal cord. b Analysis the infiltration of CD4+ T cells in a. The percentage of CD4+ T cells in spleen (c) and peripheral blood (e) were determined by flow cytometry, respectively. $d, f$ 
Analysis of CD4+ T cells in c, e. $n=3$ /group. ${ }^{*} \mathrm{P}<0.01$ and ${ }^{\star \star *} * \mathrm{P}<0.0001$ vs. the control group; $\# \mathrm{P}<$ 0.05 , \#\#P $<0.01$, and \#\#\#\#P $<0.0001$ vs. the EAE group.

a
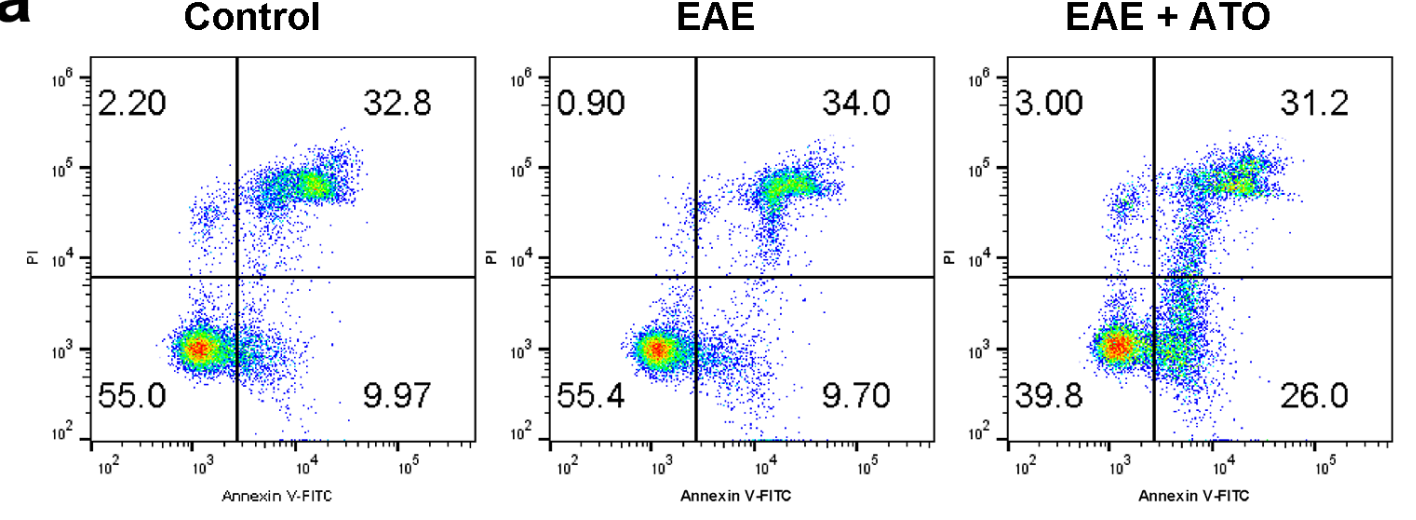

C

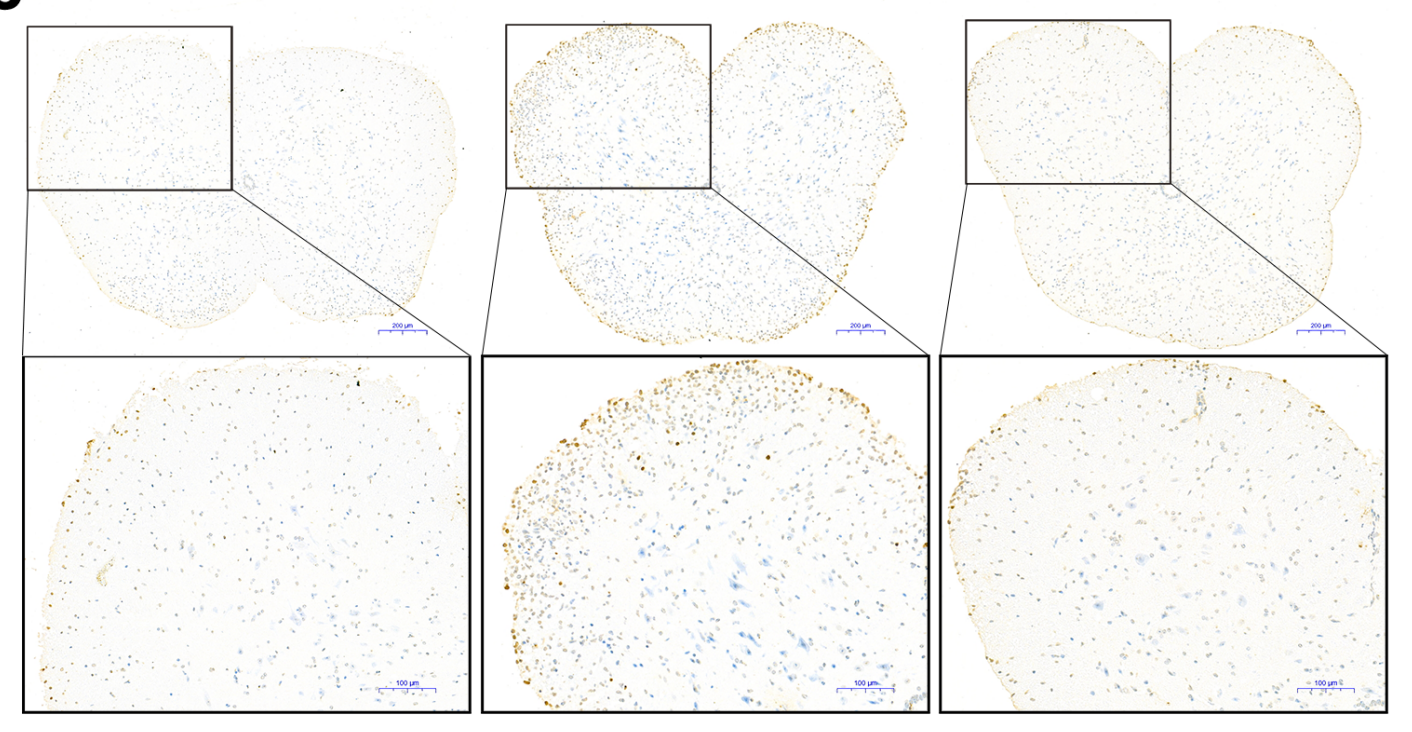

b

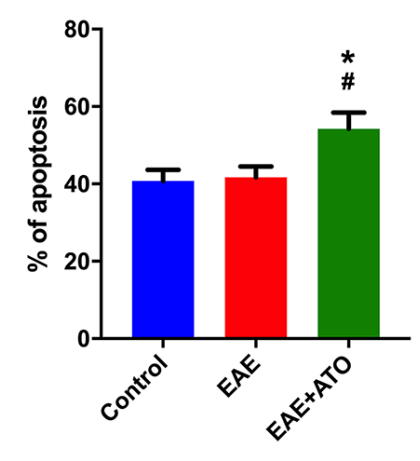

d

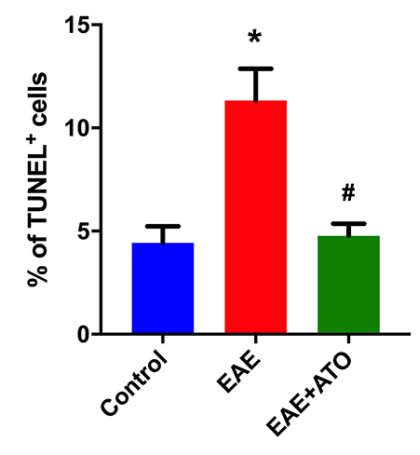

\section{Figure 5}

ATO induces CD4+ T cells apoptosis in EAE mice. a, b CD4+ T cells were isolated from the spleen with the Mouse CD4+ T cell Isolation Kit. Annexin-V/PI staining was performed to analyze the apoptosis of CD4+ T cells. c Representative TUNEL staining sections of spinal cord. Boxes show magnified areas. $d$ Analysis of TUNEL positive cells in $c . n=3 /$ group. ${ }^{*} P<0.05$ vs. the control group; $\# P<0.05$ vs. the EAE group. 
a
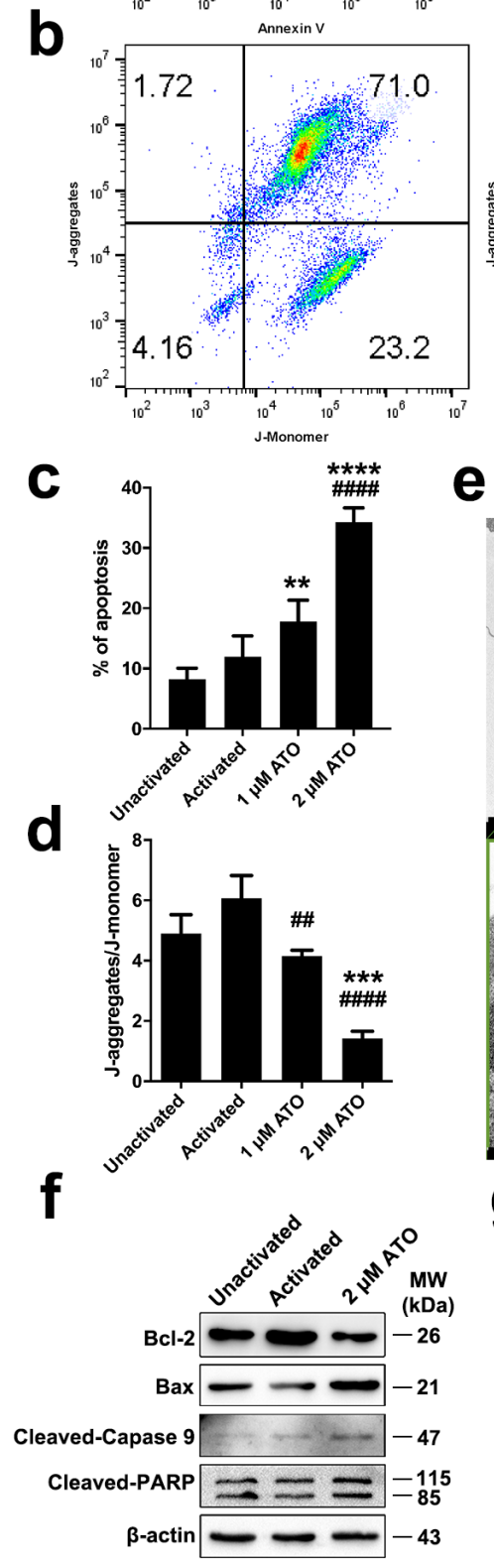

Activated
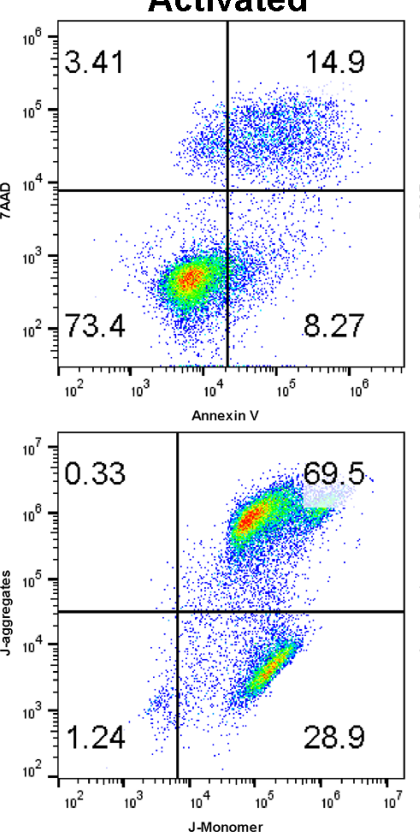

e Unactivated

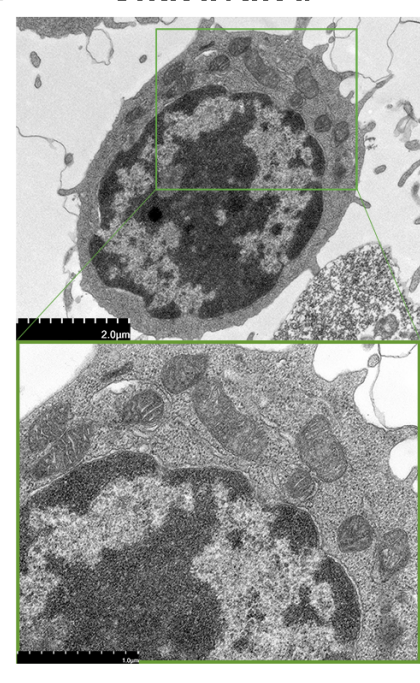

g

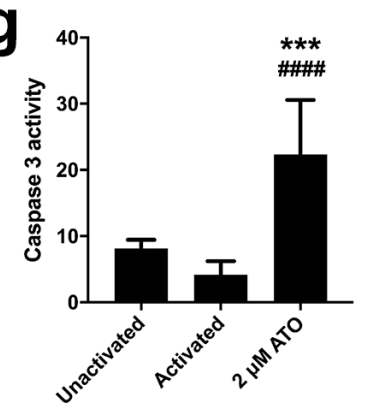

$1 \mu \mathrm{M}$ ATO
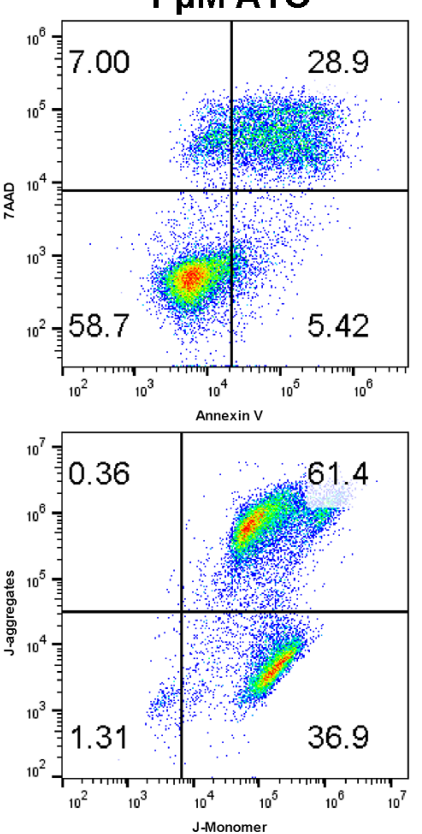

Activated

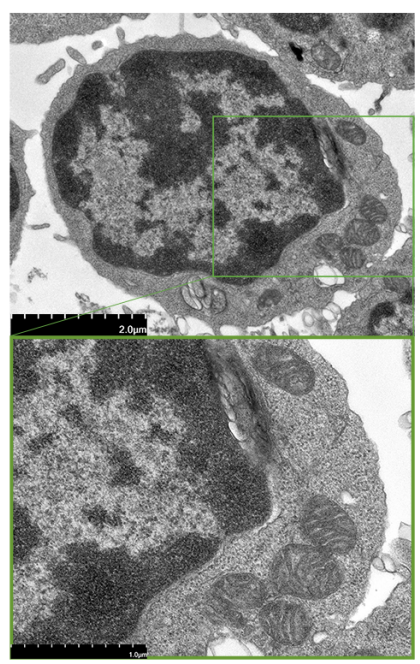

h

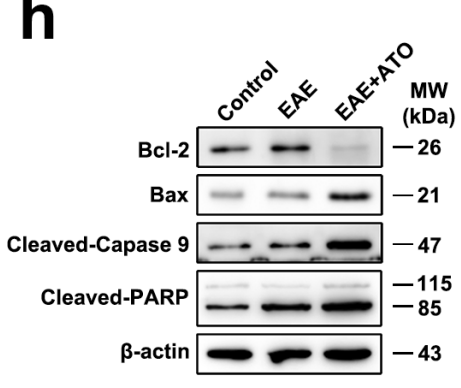

$2 \mu \mathrm{M}$ ATO
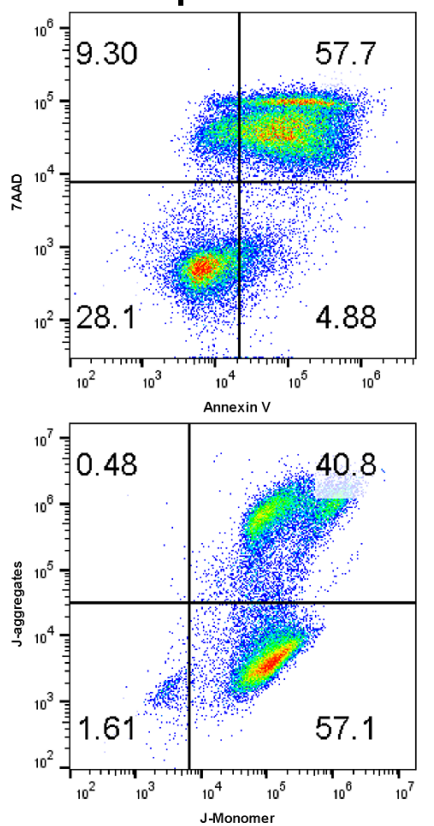

2 нM АTO
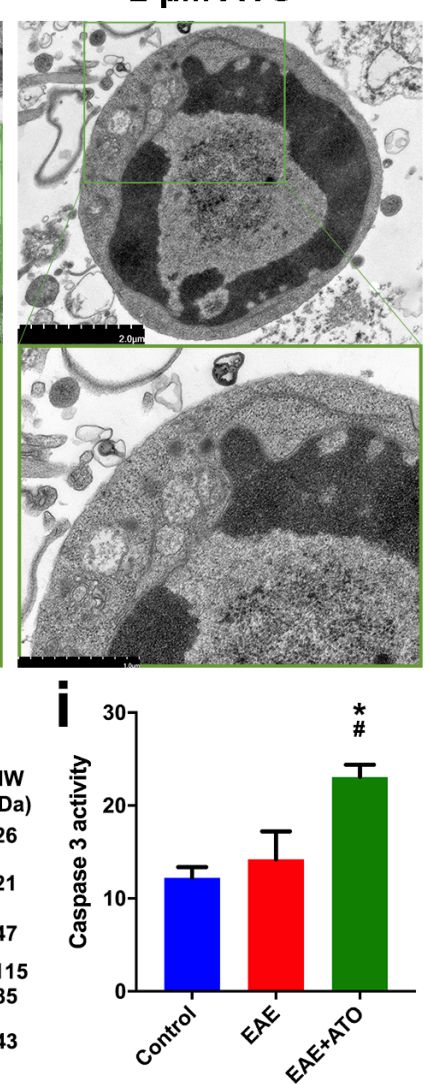

\section{Figure 6}

ATO induces CD4+ T cells apoptosis through the mitochondrial pathway. CD4+ $T$ cells were sorted from the spleen of normal mice and cultured with Con A or ATO $(0,1$, and $2 \mu \mathrm{M})$ for $24 \mathrm{~h}$. a, c Annexin V/PI was performed to evaluate the apoptosis of $\mathrm{CD} 4+\mathrm{T}$ cell. $\mathrm{b}, \mathrm{d}$ The mitochondrial membrane potential was monitored by loading with $\mathrm{JC}-1$ probe. J-aggregates indicates high membrane potential, and $\mathrm{J}$-monomers indicates low membrane potential. e The observation of mitochondrial ultrastructure by TEM. Boxes 
show magnified areas. $\mathrm{f}$ The protein level of Bax, Bcl-2, cleaved-Caspase 9, and cleaved-PARP was analyzed by western blot. $\mathrm{h}$ On day 22 post-immunization, CD4+ $\mathrm{T}$ cells isolated from the spleen were used to extract total protein. The protein level of Bax, Bcl-2, cleaved-Caspase 9, and cleaved-PARP in CD4+ $T$ cells was detected by western blot. $g$, $i$ The activity of Caspase 3 was determined with the Caspase 3 Activity Assay kit. $n=3$ /group. ${ }^{*} P<0.05,{ }^{*} P<0.01$, ${ }^{\star * *} P<0.001$, and ${ }^{* \star * * P}<0.0001$ vs. the control group; \#P $<0.05$, \#\#P $<0.01$, and \#\#\#\#P $<0.0001$ vs. the EAE group.
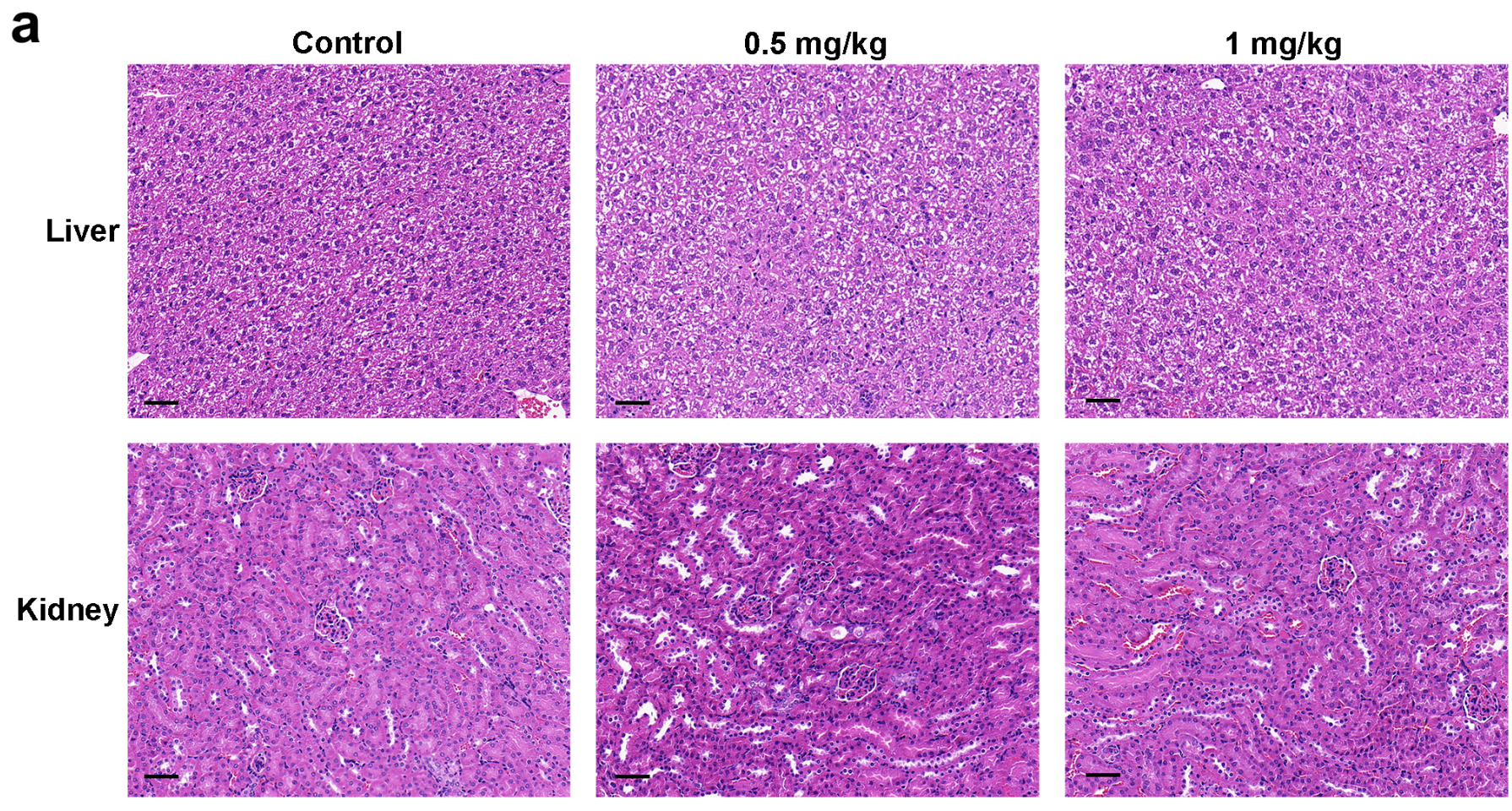

b

ALT
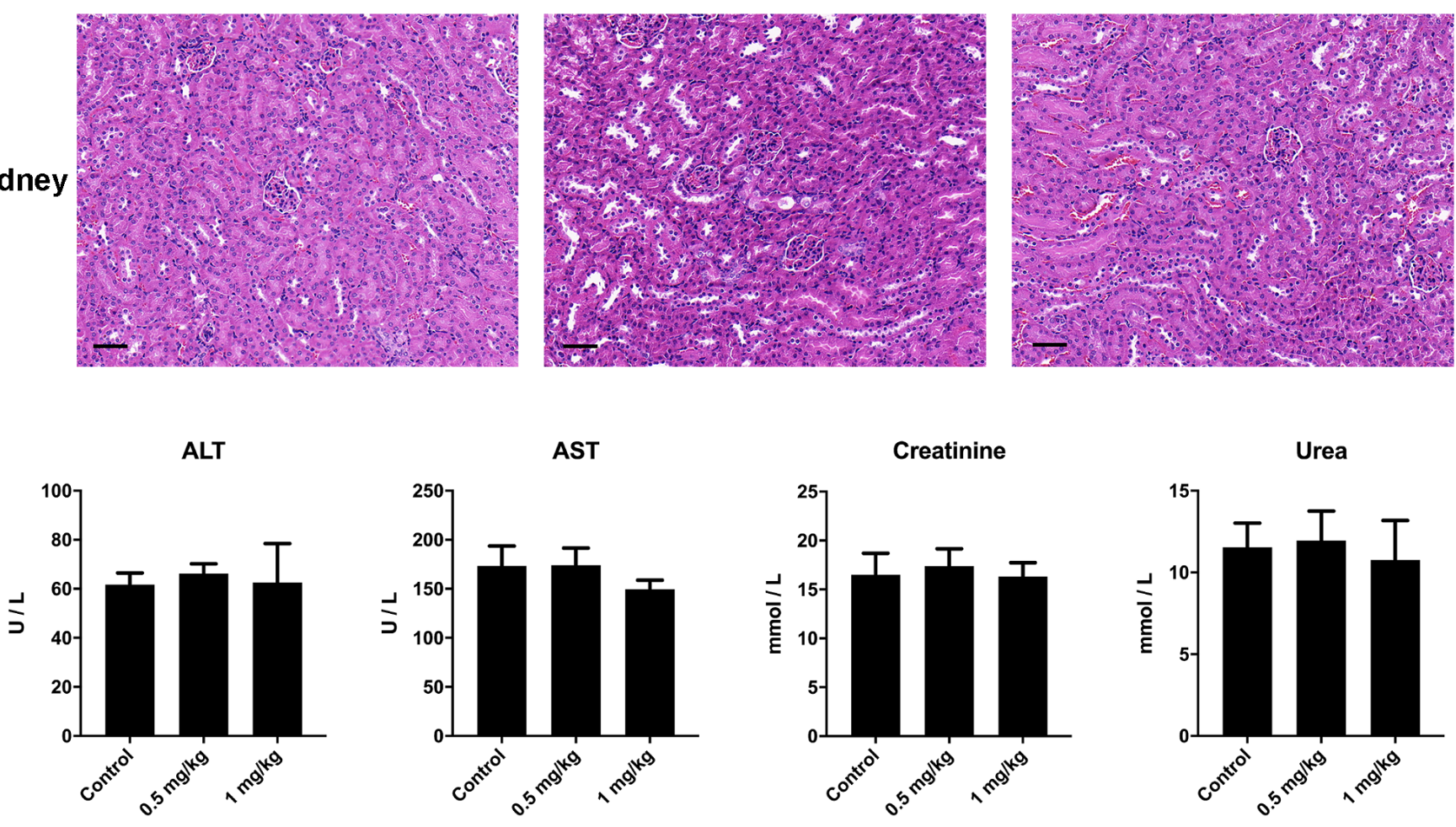

C

Control

$0.5 \mathrm{mg} / \mathrm{kg}$

$1 \mathrm{mg} / \mathrm{kg}$

Tunel

Figure 7 
No toxicity signs were observed in ATO-treated mice. Normal mice were administered intraperitoneal injections of normal saline, ATO $(0.5 \mathrm{mg} / \mathrm{kg} /$ day $)$ or ATO $(1 \mathrm{mg} / \mathrm{kg} /$ day $)$ for 20 days. a Liver and kidney were collected for HE staining. Scale bar $=50 \mathrm{~nm}$. b The levels of ALT, AST, creatinine, and urea in the serum were measured by an automated biochemical analyzer. c Representative TUNEL staining sections of the spinal cord. $n=5 /$ group. ALT, alanine aminotransferase; AST, aspartic aminotransferase. 